\title{
Sodium-based hydrides for thermal energy applications
}

\author{
D. A. Sheppard*, T. D. Humphries, C. E. Buckley \\ Hydrogen Storage Research Group, Fuels and Energy Technology Institute, Department of Physics, Astronomy and \\ Medical Radiation Sciences, Curtin University, GPO Box U1987, Perth, WA 6845, Australia.
}

*E-mail: drew.sheppard@gmail.com.

\begin{abstract}
Concentrating Solar-Thermal Power (CSP) with Thermal Energy Storage (TES) represents an attractive alternative to conventional fossil fuels for base-load power generation. Sodium alanate $\left(\mathrm{NaAlH}_{4}\right)$ is a well-known sodium-based complex metal hydride but, more recently, high-temperature sodium-based complex metal hydrides have been considered for TES. This review considers the current state-of-the-art for $\mathrm{NaH}, \mathrm{NaMgH}_{3-\mathrm{x}} \mathrm{F}_{x}, \mathrm{Na}$-based transition metal hydrides, $\mathrm{NaBH}_{4}$ and $\mathrm{Na}_{3} \mathrm{AlH}_{6}$ for TES and heat pumping applications. These metal hydrides have a number of advantages over other classes of heat storage materials such as high thermal energy storage capacity, low volume, relatively low-cost and a wide range of operating temperatures $\left(100^{\circ} \mathrm{C}\right.$ to more than $\left.650{ }^{\circ} \mathrm{C}\right)$. Potential safety issues associated with the use of high-temperature sodium-based hydrides are also addressed.
\end{abstract}

\section{Introduction}

Sodium forms a major component of a wide range of metal hydrides from the simple binary NaH to complex transition metal hydrides (e.g. $\mathrm{Na}_{3} \mathrm{RuH}_{7}, \mathrm{Na}_{2} \mathrm{Mg}_{2} \mathrm{FeH}_{8}$ ) [1-3], borohydrides (e.g. $\mathrm{NaBH}_{4}, \mathrm{NaSc}\left(\mathrm{BH}_{4}\right)_{4}$ ) [4-7], alanates (e.g. $\mathrm{NaAlH}_{4}, \mathrm{Na}_{2} \mathrm{LiAlH}_{6}$ ) and perovskite hydrides (e.g. $\mathrm{NaMgH}_{3}, \mathrm{NaMgH}_{3-x} \mathrm{~F}_{x}$ ) [8-11]. Much of the collective focus around metal hydrides has been towards the development of a hydrogen storage material suitable for mobile applications $[12,13]$. However, the majority of sodium-based hydrides have high thermodynamic stability that makes them potential candidates for heat storage and heat pumping applications that span the temperature range of $100{ }^{\circ} \mathrm{C}$ to more than $600^{\circ} \mathrm{C}$. In addition to high thermodynamic stability, the properties of the ideal metal hydride for TES or heat pumping applications would include: flat $\mathrm{H}_{2}$ absorption/desorption plateaux, low hysteresis, fast $\mathrm{H}_{2}$ sorption kinetics, high $\mathrm{H}_{2}$ capacity, a stable $\mathrm{H}_{2}$ capacity (over thousands of cycles), and, depending on the application, low cost. The rate of heat transfer within the hydride bed (i.e. the thermal conductivity) is also a consideration, whose importance is dependent on the demands of a particular application [10, 11, 14-16].

Metal hydrides have demonstrated their engineering feasibility in a large number of energy related applications including: hydrogen compression; heat storage; thermally driven temperature-upgrading; thermally driven heat upgrading; thermally driven refrigeration and; as heat engines $[17,18]$. The principles behind the use of metal hydrides for these applications is reviewed in a number of articles [17-22]. While much of the theory and proof-ofconcept for metal hydrides for these applications was developed in the 1970s and 1980s, a number of factors have prevented the commercial deployment of these materials. The first is that, during this period of development, the primary metal hydrides available were transition metal intermetallic hydrides based on $A B, A B_{2}$ and $A B_{5}$ alloys (where $A$ = hydride forming metal such as $\mathrm{Ti}, \mathrm{Zr}$, La, Ce and $B=$ non-hydride forming metal such as $\mathrm{Cr}, \mathrm{Mn}, \mathrm{Fe}, \mathrm{Co}$ or $\mathrm{Ni}$ ). These hydrides generally exhibit plateau slope and hysteresis as well as some hydrogen solubility behaviour that reduces the efficiency of practical systems constructed from them [18, 20]. The relatively low $\mathrm{H}_{2}$ capacity (practical $\mathrm{H}_{2}$ capacities typically range between 1.0 and $1.7 \mathrm{wt} \%$ ) and high cost of intermetallic hydrides [23] means that these systems can't compete economically with commercially available heat pumping systems based on lithium bromide/water, activated carbon/methanol or zeolite/water that operate between $0{ }^{\circ} \mathrm{C}$ and $120{ }^{\circ} \mathrm{C}[16,19]$. However, intermetallic hydrides have demonstrated a unique ability to exploit and upgrade low-grade industrial heat at temperatures of between $100^{\circ} \mathrm{C}$ and $300^{\circ} \mathrm{C}[18,20]$ but this ability has failed to translate to commercial products due to the tendency for intermetallic hydrides to disproportionate and lose $\mathrm{H}_{2}$ capacity when extensively cycled in this temperature range $[20,24]$. 
In general, sodium-based hydrides (SBHs) have a number of advantages over conventional intermetallic hydrides such as: flat hydrogen absorption/desorption plateaux; little or no hysteresis; higher $\mathrm{H}_{2}$ capacity and lower cost [11, $15,25]$. This means that SBHs have the potential to be commercially viable in applications where traditional intermetallic hydrides have proven to be feasible but are too expensive.

SBHs can generally be separated into two categories based on their operating temperature range: those that operate between $\sim 100^{\circ} \mathrm{C}$ and $\sim 400{ }^{\circ} \mathrm{C}$ and form $\mathrm{NaH}$ as one of their thermal decomposition products during $\mathrm{H}_{2}$ release (SBH Category I) and those that operate at temperatures greater than $400^{\circ} \mathrm{C}$ and form metallic Na during $\mathrm{H}_{2}$ release (SBH - Category II). Category I SBHs have potential for medium-temperature $\left(150{ }^{\circ} \mathrm{C}-400{ }^{\circ} \mathrm{C}\right)$ heat storage and as chemical heat pumps for thermally driven temperature-upgrading and thermally driven heat-upgrading applications in chemical and agricultural food industries $[16,18,19]$. The main potential of Category II SBHs is as TES systems for Concentrating Solar Power (CSP). A metal hydride TES (MH-TES) system requires pairing two different metal hydrides: the high-temperature metal hydride $(\mathrm{HTMH})$ to act as the heat storage material and the low-temperature metal hydride (LTMH) to act as the hydrogen store. Detailed descriptions of their operation can be found elsewhere [26-28]. A MH-TES has the potential to supersede current state-of-the-art CSP heat storage using molten nitrate salts (40 wt\% $\mathrm{NaNO}_{3}, 60 \mathrm{wt} \% \mathrm{KNO}_{3}$ ) [29]. Initial techno-economic assessments of Na-based TES systems for CSP yielded installed costs of $29.8-54.0$ US\$. $\mathrm{kWh}_{t h}{ }^{-1}[10,15,25]$. This compares well with values for molten nitrate salt technology of $30-80 \mathrm{US \$} \cdot \mathrm{kWh}_{t h}{ }^{-1}[30,31]$, especially considering that the assessment of MH-TES systems did not use an optimised engineering design. Molten nitrate salts also have a number of disadvantages as a heat storage medium that includes: a maximum operating temperature limited by their decomposition at $\sim 600{ }^{\circ} \mathrm{C}$ [29]; additional insulation and heating equipment requirements to prevent freezing of the nitrate salt ( $\mathrm{MP}=238^{\circ} \mathrm{C}$ ) [29]; the need for salt-compatible components [32] and; parasitic energy losses that exceed $10 \%$ of the electricity generated (primarily due to the molten salt receiver pumps) [31]. Molten nitrate salts have a gravimetric and volumetric heat storage capacity of $167 \mathrm{~kJ} \cdot \mathrm{kg}^{-1}$ and $88 \mathrm{~kJ} \cdot \mathrm{L}^{-1}$, respectively, when used for heat storage in parabolic trough CSPs that operate at $\sim 400{ }^{\circ} \mathrm{C}$ and values of $414 \mathrm{~kJ} \cdot \mathrm{kg}^{-1}$ and $218 \mathrm{~kJ} \cdot \mathrm{L}^{-1}$, respectively, when used for heat storage in power tower CSPs that operate at $565^{\circ} \mathrm{C}$ [33]. These values are compared in Fig. 1(a) and Table 1 with the theoretical gravimetric and volumetric heat storage capacities of various SBHs and Mg-based hydrides that can be used as HTMHs. It should be noted though that the values quoted are for the high-temperature metal hydrides only and does not consider the mass and volume of the low-temperature $\mathrm{H}_{2}$ storage. While taking into account the low-temperature $\mathrm{H}_{2}$ storage reduces the gravimetric and volumetric capacity of a MH-TES by a factor of between 2 and 3 [15], their capacities still exceed those of molten salt system several times over. Furthermore, the maximum operating temperature of molten nitrate salts is $\sim 565^{\circ} \mathrm{C}$ [32], since they decompose at $600^{\circ} \mathrm{C}$ [29], but a number of MH-TES systems have the potential to operate well above $565^{\circ} \mathrm{C}$ (Table 1). The maximum operating temperature for a particular HTMH is primarily dependent on engineering considerations as the $\mathrm{H}_{2}$ equilibrium pressure of metal hydrides increases exponentially with temperature. Fig 1 (b) shows the $\mathrm{H}_{2}$ equilibrium pressure for various $\mathrm{SBH}$ s as a function of temperature.

This review examines the current state-of-the-art of SBHs for both TES and heat pumping applications. In many SBHs, basic properties, such as intrinsic kinetics of $\mathrm{H}_{2}$ absorption/desorption, reversibility, cyclic stability, and thermal conductivity have not been adequately characterised. Challenges and future research directions from a materials characterisation, engineering and safety perspective are discussed. 

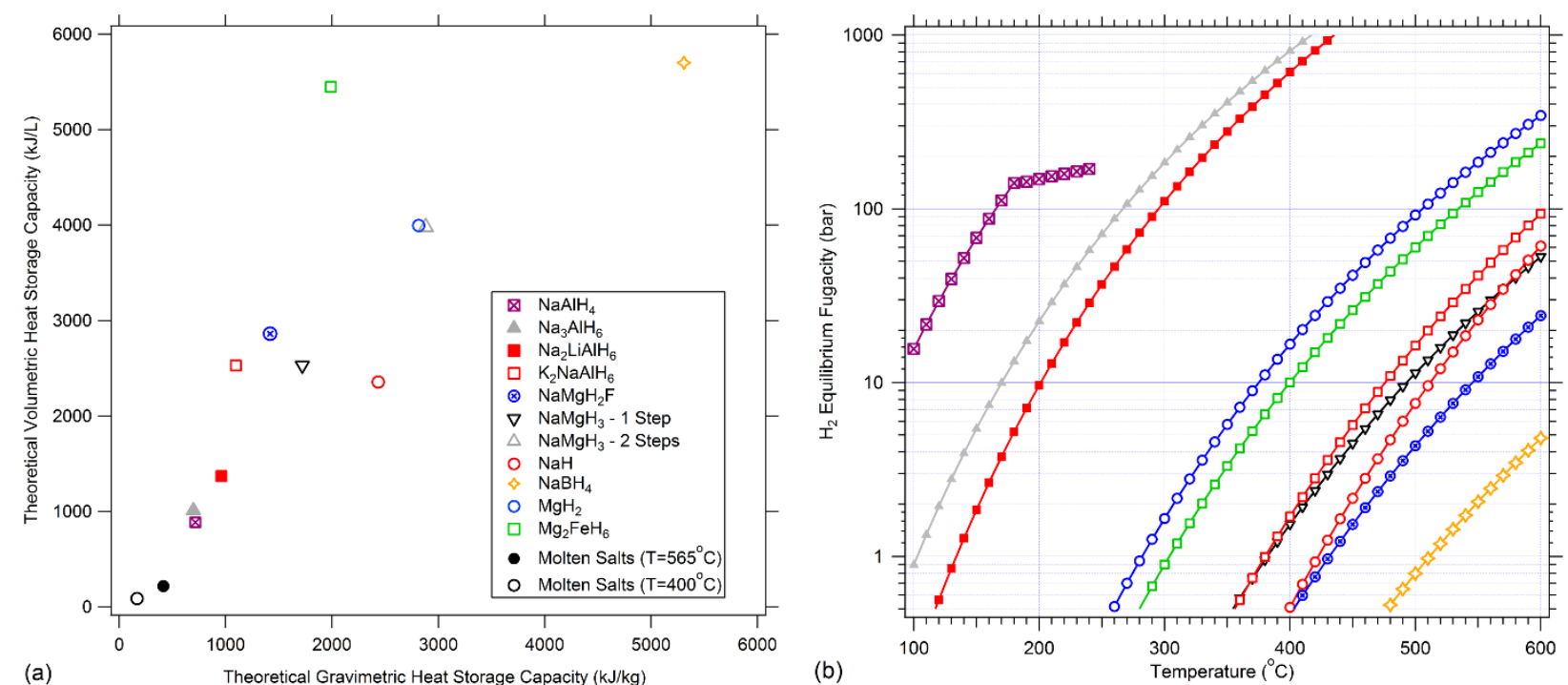

Fig. 1. (a) Volumetric heat storage capacities versus gravimetric heat storage capacities for various Na-based hydrides. (b) Pressure versus temperature for various Na-based hydrides.

Table 1. Properties of selected metal hydrides and calculated operating temperatures between 1 and 150 bar*.

\begin{tabular}{|c|c|c|c|}
\hline Material & $\begin{array}{c}\text { Theoretical } \mathbf{H}_{\mathbf{2}} \\
\text { capacity (wt\%) }\end{array}$ & $\begin{array}{c}\boldsymbol{\Delta H} \\
\left(\mathbf{k J} \cdot \mathbf{m o l}^{-\mathbf{1}} \mathbf{H}_{\mathbf{2}}\right)\end{array}$ & $\begin{array}{c}\text { Operating range } \\
\left({ }^{\circ} \mathbf{C}\right)\end{array}$ \\
\hline $\mathrm{NaAlH}_{4}$ & 3.73 & $38.4[34]$ & $31-181$ \\
\hline $\mathrm{Na}_{3} \mathrm{AlH}_{6}$ & 2.96 & $47.4[34]$ & $103-288$ \\
\hline $\mathrm{Na}_{2} \mathrm{LiAlH}_{6}$ & 3.52 & $54.95^{\ddagger}$ & $134-316$ \\
\hline $\mathrm{K}_{2} \mathrm{NaAlH}_{6}$ & 2.25 & $98[35]$ & $380-631$ \\
\hline $\mathrm{NaMgH}_{2} \mathrm{~F}$ & 2.95 & $96.8[10]$ & $431-738$ \\
\hline $\mathrm{NaMgH}_{3}-1 \mathrm{Step}$ & 4.01 & $86.6[11]$ & $382-683$ \\
\hline $\mathrm{NaH}^{2}$ & 4.20 & $116.8[36]$ & $426-659$ \\
\hline $\mathrm{NaBH}_{4}$ & 10.67 & $100.4[33]$ & $511-890$ \\
\hline $\mathrm{MgH}_{2}$ & 7.66 & $74[37]$ & $282-534 \dagger$ \\
\hline $\mathrm{Mg}_{2} \mathrm{FeH}_{6}$ & 5.47 & $77[37]$ & $304-564$ \\
\hline
\end{tabular}

*Pressures noted correspond to calculated fugacities (Pressure $=$ Fugacity/compressibility of $\mathrm{H}_{2}$ ).

†Maximum temperature unachievable due to sintering [38].

†The average of refs [39] and [40].

\section{History of Sodium and Sodium Hydride}

Research on the interaction between hydrogen gas and metallic sodium to form sodium hydride $(\mathrm{NaH}, \mathrm{SBH}=$ Category II) began more than 140 years ago in 1874 [36]. Fortuitously, sodium hydride has a large number of attributes that make it attractive as a high temperature TES system for CSP. It has a respectable theoretical hydrogen storage capacity $\left(4.2 \mathrm{wt} \% \mathrm{H}_{2}\right)$, a high enthalpy of $\mathrm{H}_{2}$ absorption $\left(\Delta H_{a b s}=-114 \mathrm{~kJ} \cdot \mathrm{mol}^{-1} \mathrm{H}_{2}\right)$ [41] and, from pressurecomposition isotherms, a wide and flat plateau with limited $\mathrm{H}_{2}$ solubility [42]. In addition, a significant level of research into the sodium-hydrogen system has been driven by the use of liquid sodium as a coolant in liquid-metal fast-breeder reactors and, as a result, a large body of knowledge exists pertaining to the safe production, handling, containment and use of high temperature sodium on an industrial scale [43]. NaH is used as reagent in the production of $\mathrm{NaBH}_{4}$ [44], as a descaling agent for the removal of surface oxides from metals (when combined with molten sodium hydroxide) [45] and is also utilised as a strong base in the chemical synthesis, e.g. the deprotonation of Brønsted acids, as a reducing agent and as a drying agent [46]. As a result, $\mathrm{NaH}$ is relatively cheap compared to most metal hydrides [10, 15, 25]. 
All of these factors suggest that $\mathrm{NaH}$ would be an ideal thermal storage medium (at least up to the melting point of $\mathrm{NaH}\left(640^{\circ} \mathrm{C}\right)$ ), except for the fact that it has almost negligible reversibility. Molten $\mathrm{Na}$ reacts with $\mathrm{H}_{2}$ to form a thin surface layer of solid $\mathrm{NaH}$ that inhibits further absorption of $\mathrm{H}_{2}$. This complication can be addressed by mechanical grinding $\mathrm{Na}$ under a $\mathrm{H}_{2}$ atmosphere at a temperature of $260^{\circ} \mathrm{C}$ to $370{ }^{\circ} \mathrm{C}[47,48]$. However, it is unlikely that these techniques would be suitable or cost effective on the scale required for CSP. For the industrial scale production of $\mathrm{NaH}$, the problem of slow hydriding of molten $\mathrm{Na}$ is circumvented by dispersing molten $\mathrm{Na}$ in a high boiling point hydrocarbon, such as mineral oil, to create an emulsion. With the emulsion maintained at temperatures of $250{ }^{\circ} \mathrm{C}$ to $300{ }^{\circ} \mathrm{C}$, hydrogen is bubbled through the system and the small size of the dispersed $\mathrm{Na}$ (typically about $10 \mu \mathrm{m}$ ) allows for hydrogenation [45]. Again, this technique is unsuitable when considering $\mathrm{Na} / \mathrm{NaH}$ as part of a TES system that operates above $400^{\circ} \mathrm{C}$ due to the temperature limitations of hydrocarbons [32].

A further complication of Category II SBHs is the high vapour pressure of molten sodium metal that causes its distillation at the temperatures relevant for TES [41, 42]. This problem was solved by sealing NaH within thin walled iron tubes that are permeable to $\mathrm{H}_{2}$ but not sodium vapour $[7,41,42]$. The relatively slow diffusion of $\mathrm{H}_{2}$ through the iron walls means that temperatures greater than $550{ }^{\circ} \mathrm{C}$ are required for reasonable $\mathrm{H}_{2}$ desorption kinetics, and this technique does not address the difficulties associated with rehydriding molten $\mathrm{Na}$ metal to form solid $\mathrm{NaH}[7,41$, 42].

Despite the difficulties due to distillation and hydriding of $\mathrm{Na}$ at high temperatures, its potential has led to research efforts at Curtin University in exploring $\mathrm{Na} / \mathrm{NaH}$ as a TES system for CSP. Fig. 2(a) displays the hydrogen desorption and the attempted absorption at $452{ }^{\circ} \mathrm{C}$ from commercially available $\mathrm{NaH}$ (Sigma Aldrich, 95\% purity). The desorption plateau of $\mathrm{NaH}$ would normally be flat, but is unfortunately distorted by the $\mathrm{NaOH}$ impurity that is present in the commercially available material. Note that, even with a very long wait time, the $\mathrm{H}_{2}$ re-absorption is minimal due to the $\mathrm{NaH}$ skin effect. Fig. 2(b) displays the hydrogen sorption, performed at $472{ }^{\circ} \mathrm{C}$, on a modified $\mathrm{NaH}$ sample developed at Curtin University. In this instance $\mathrm{H}_{2}$ absorption is fully reversible and the minor hysteresis is only an artefact of the fact that the wait-time for each desorption step was shorter than the wait-time for each absorption step. The practical gravimetric and volumetric heat storage capacity of this sample was $1946 \mathrm{~kJ}^{\mathrm{kg}} \mathrm{kg}^{-1}$ and $1778 \mathrm{~kJ} \cdot \mathrm{L}^{-1}$ which are $80 \%$ and $75 \%$, respectively, of the theoretical values. While the modified sample from Fig. 2(b) was successful in preventing Na vaporisation at $472{ }^{\circ} \mathrm{C}$, this effect did not extend to $500{ }^{\circ} \mathrm{C}$ and further work is required to enhance its upper operating temperature. 

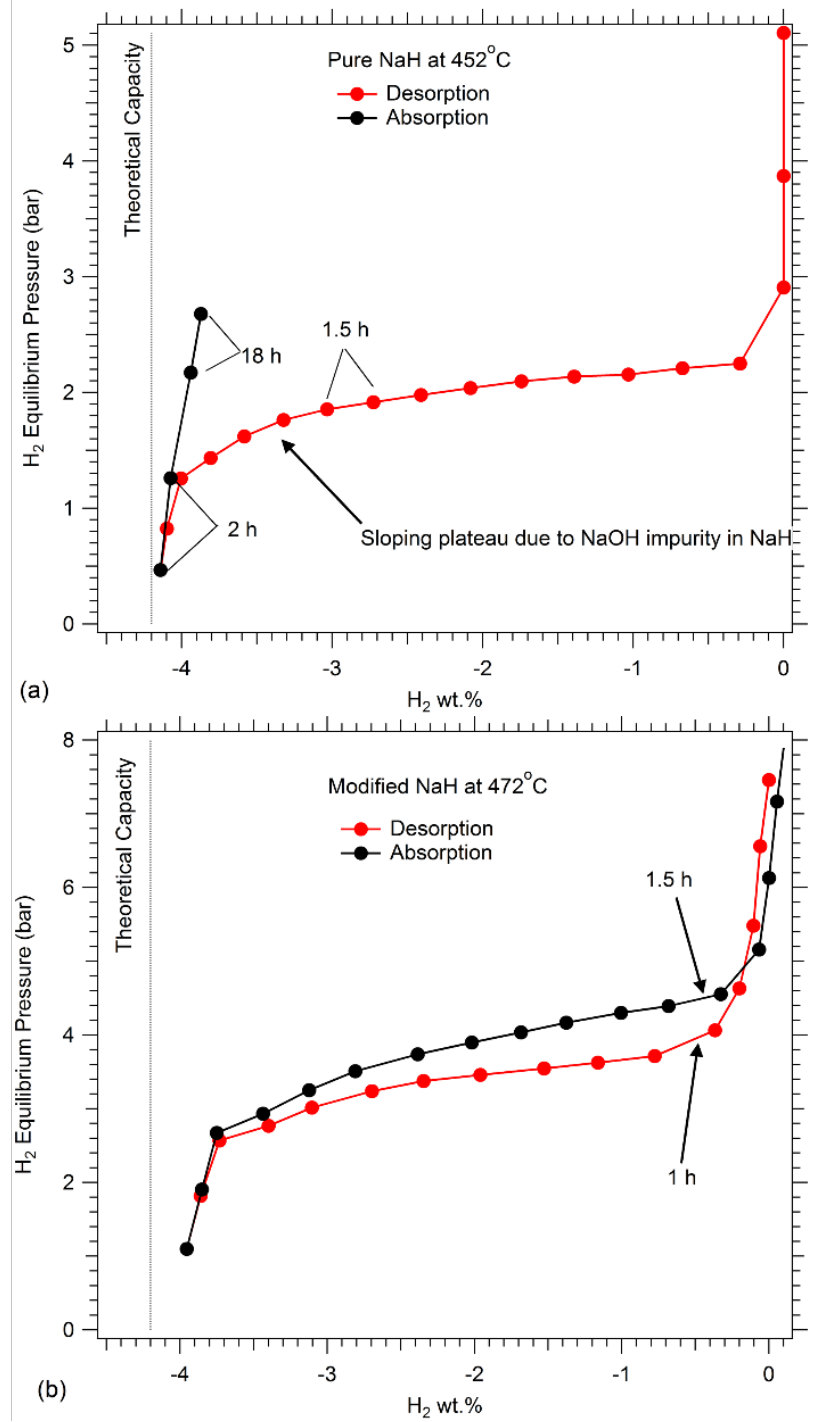

Fig. 2. Cycling studies of (a) Pure $\mathrm{NaH}$ and (b) modified $\mathrm{NaH}$ conducted at Curtin University. $\mathrm{H}_{2}$ capacity is reported relative to $\mathrm{NaH}$ content only [49].

Due to its large scale industrial use, $\mathrm{Na}$ (and by extension, $\mathrm{NaH}$ ) is relatively cheap with a 2006 price US\$3.48/kg for reactor grade purity [50]. As was previously discussed, this Na price results in TES systems that have the potential to be cost competitive with current state-of-the-art molten salt systems. However, alternative methods for the production of $\mathrm{Na}$ and $\mathrm{NaH}$ have been explored [51] and have the potential to reduce its cost by up to a factor of 10 . Such a development would place TES systems based on SBHs at a distinct economic advantage.

\section{3. $\mathrm{NaMgH}_{3}$ and $\mathrm{MaNgH}_{3-x} \mathrm{~F}_{x}$}

\section{1 $\mathrm{NaMgH}_{3}$}

The perovskite hydride, $\mathrm{NaMgH}_{3}$, was first suggested to be a stable compound based on the structural similarity between other perovskite hydrides and fluorides [52]. It can readily be synthesised by annealing the respective elements or their hydrides $[11,53] . \mathrm{NaMgH}_{3}$ undergoes a two-step hydrogen desorption and so can be classed as either a Category I or Category II SBH depending on the choice of operating conditions. For the first step (Eq. 1), 4.0 wt\% $\mathrm{H}_{2}$ is released, while 2.0 wt $\% \mathrm{H}_{2}$ is released during the second step (Eq. 2).

$\mathrm{NaMgH}_{3} \rightleftarrows \mathrm{NaH}+\mathrm{Mg}+\mathrm{H}_{2}$

$\mathrm{NaH}+\mathrm{Mg} \rightleftarrows \mathrm{Na}(\mathrm{l})+\mathrm{Mg}+1 / 2 \mathrm{H}_{2}$

From Pressure-Composition-Isotherm (PCl) measurements (Fig. 3), the enthalpy, $\Delta H_{\text {des, }}$ and entropy, $\Delta S_{\text {des, }}$ of desorption for Eq. 1 were determined as $86.6 \mathrm{~kJ} \cdot \mathrm{mol}^{-1} \mathrm{H}_{2}$ and $132.2 \mathrm{~J} \cdot \mathrm{mol}^{-1} \mathrm{H}_{2} \cdot \mathrm{K}^{-1}$ and, importantly for practical 
applications, the plateau was found to have negligible slope and hysteresis. The enthalpy and entropy of desorption for Eq. 2 corresponds to those for pure $\mathrm{NaH}\left(\Delta H_{\text {des }}=116 . \mathrm{kJ} \cdot \mathrm{mol}^{-1} \mathrm{H}_{2}\right.$ and $\left.\Delta S_{\text {des }}=168.2 \mathrm{~J} \cdot \mathrm{mol}^{-1} \mathrm{H}_{2} \cdot \mathrm{K}^{-1}\right)$ [36]. Combined, the theoretical gravimetric heat storage capacity of Eq. 1 and Eq. 2 is $2881 \mathrm{~kJ}^{\mathrm{kg}} \mathrm{gg}^{-1}$ (Eq. $1=1721 \mathrm{~kJ} \cdot \mathrm{kg}^{-1}$, Eq. $2=1160$ $\mathrm{kJ} \cdot \mathrm{kg}^{-1}$ ). The full decomposition of $\mathrm{NaMgH}_{3}$ into $\mathrm{Mg}$ and $\mathrm{Na}$ results in the agglomeration and distillation of molten $\mathrm{Na}$ that results in a loss of capacity upon cycling at $500^{\circ} \mathrm{C}[11,25,54]$. Initial research over 10 cycles suggests that this capacity loss may stabilise after 7 cycles [25]. As a result of this capacity loss, only the heat storage capacity of Eq. 1 is generally considered for TES. Despite this, when $\mathrm{NaMgH}_{3}$ is compared to other leading metal hydrides for heat storage [37], $\mathrm{MgH}_{2}, \Delta H_{\text {des }} \sim 74 \mathrm{~kJ} \cdot \mathrm{mol}^{-1} \mathrm{H}_{2}$, and $\mathrm{Mg}_{2} \mathrm{FeH}_{6}, \Delta H_{\text {des }} \sim 77 \mathrm{~kJ} \cdot \mathrm{mol}^{-1} \mathrm{H}_{2}$ (Table 1), the higher enthalpy of Eq. 1 for $\mathrm{NaMgH}_{3}$ results in a number of advantages: (1) lower hydrogen dissociation pressures, particularly at temperatures above $500^{\circ} \mathrm{C}$ (Fig. 4) and; (2) less $\mathrm{H}_{2}$ is required to generate the same amount of thermal energy. For metal hydrides as TES systems in CSP, the relatively high cost of ambient (or near-ambient) $\mathrm{H}_{2}$ storage means that any reductions in the amount of $\mathrm{H}_{2}$ in the system decreases the overall installed system cost $[10,15]$. Two facets that require further investigation are whether Eq. 1 maintains its hydrogen capacity during cycling if the decomposition of $\mathrm{NaH}$ to molten $\mathrm{Na}$ is avoided and whether the upper operating temperature for Eq. 1 is limited to $\sim 570^{\circ} \mathrm{C}$. At this temperature the two-step decomposition of $\mathrm{NaMgH}_{3}$ is expected to transform into a single step reaction (indicated by the arrow in Fig. 4 inset) that, similar to the $\mathrm{KMgH}_{3}$ system [55], may have limited reversibility.

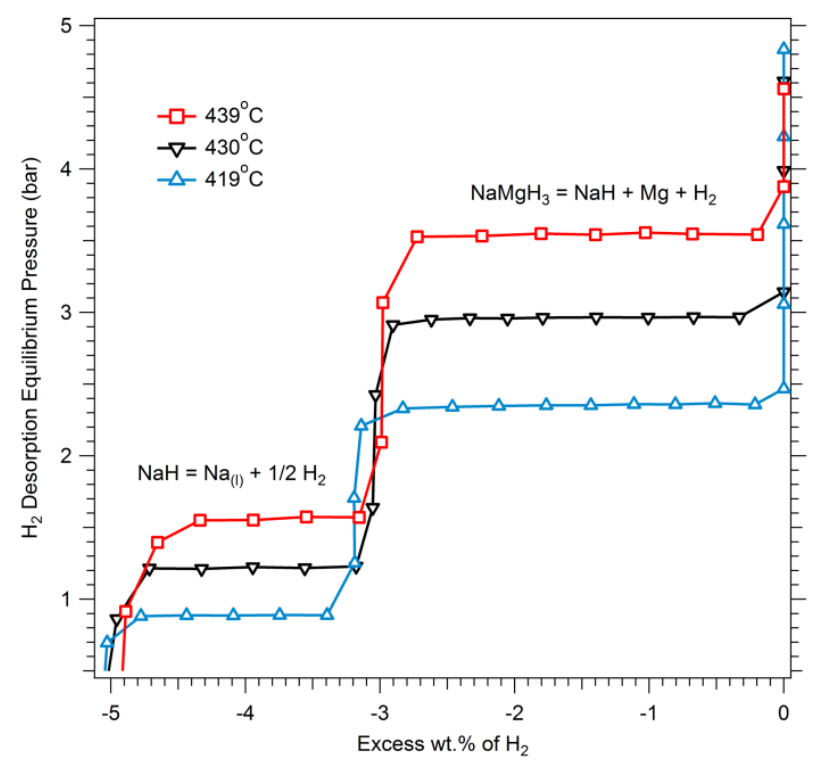

Fig. 3. Desorption $\mathrm{PCl}$ measurements performed on $\mathrm{NaMgH}_{3}$ that show plateaux reactions that correspond to Eq. 1 and Eq. 2, respectively. 


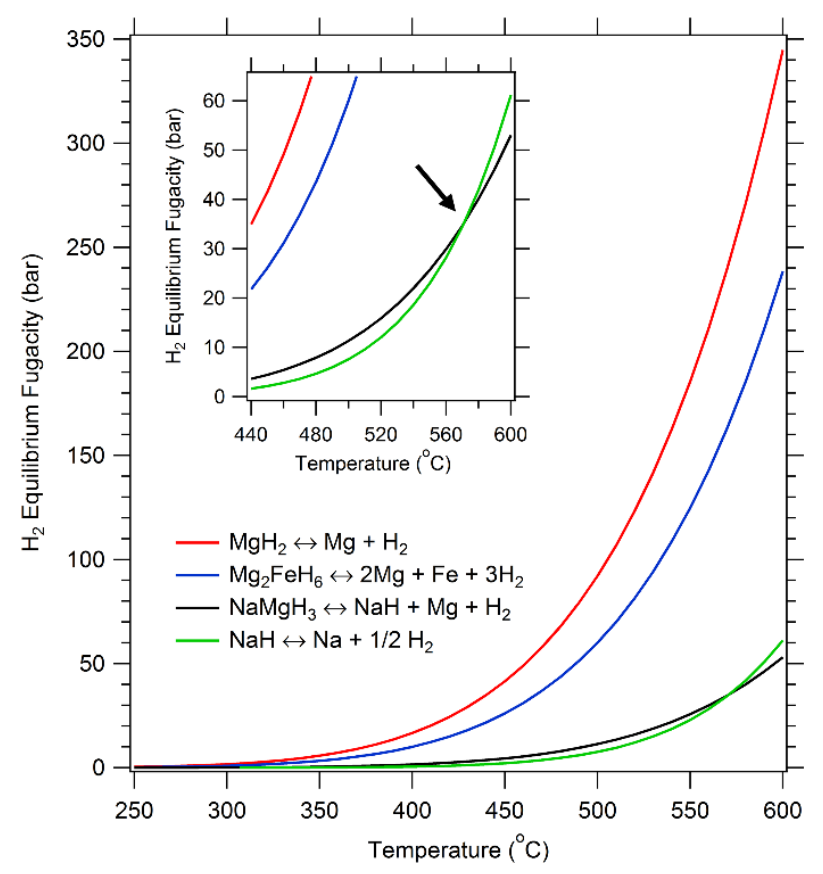

Fig. 4. Hydrogen equilibrium pressure as a function of temperature for $\mathrm{NaMgH}_{3}, \mathrm{MgH}_{2}$ and $\mathrm{Mg}_{2} \mathrm{FeH}_{6}$.

\section{2 $\mathrm{NaMgH}_{2} \mathrm{~F}$}

Investigations into the thermodynamic properties of $\mathrm{NaMgH}_{3-\mathrm{x}} \mathrm{F}_{x}$ system commenced in 1999, swiftly followed by the formal structural characterisation of $\mathrm{NaMgH}_{2} \mathrm{~F}$ in 2000 [8, 9]. Direct hydrogenation (10 bar) of $\mathrm{Mg}$ and $\mathrm{NaF}$ at $480^{\circ} \mathrm{C}$ for $24 \mathrm{~h}$, induces the formation of this orthorhombic perovskite that exists in the same space group as $\mathrm{NaMgH}_{3}$ and $\mathrm{NaMgF}_{3}(P n m a)$ [9]. The initial determinations of the standard enthalpies of formation for $\mathrm{NaMgH}_{3}$ and $\mathrm{NaMgH}_{2} \mathrm{~F}$ were determined by calorimetry using their reaction with $0.5 \mathrm{M} \mathrm{HCl}\left(\Delta_{\mathrm{f}} \mathrm{H}^{0}\right.$ of $-231 \pm 4$ and $-720 \pm 8 \mathrm{~kJ} \cdot \mathrm{mol}^{-1}$ for $\mathrm{NaMgH}_{3}$ and $\mathrm{NaMgH}_{2} \mathrm{~F}$, respectively) [8]. The dramatic increase in $\Delta H$ by the substitution of one $\mathrm{H}$ by $\mathrm{F}$ underpinned the idea that $\mathrm{NaMgH}_{2} \mathrm{~F}$ would possess the ideal thermodynamic properties required for TES, potentially without the evaporative loss of $\mathrm{Na}$ inherent in the decomposition of $\mathrm{NaMgH}_{3}$.

This preliminary work was furthered by the precise characterisation of the decomposition process and also the determination of $\Delta H_{\text {des }}$ and $\Delta S_{\text {des }}$ of $\mathrm{NaMgH}_{3}$ (see Section 3.1) and $\mathrm{NaMgH}_{2} \mathrm{~F}$ by PCl measurements [10]. Below $478^{\circ} \mathrm{C}$, decomposition of $\mathrm{NaMgH}_{2} \mathrm{~F}$ occurs in a two-step process (Eq. 3.), similar to that of $\mathrm{NaMgH}_{3}$, while above this temperature a marked difference is observed, with only one plateau being observed (Fig. 5). This is indicative of the existence of a randomly distributed solid solution, rather than a stoichiometric hydride phase. Overall, the singlestep decomposition process has a $\Delta H_{\text {des }}=96.8 \mathrm{~kJ} \cdot \mathrm{mol}^{-1} \mathrm{H}_{2}$ and $\Delta S_{\text {des }}=137.4 \mathrm{~J} \cdot \mathrm{mol}^{-1} \cdot \mathrm{K}^{-1} \mathrm{H}_{2}$. Rehydrogenation of this material is reported to be slow at $450^{\circ} \mathrm{C}$ with hysteresis being observed during cycling due to kinetic limitations [10]. At 470 and $491{ }^{\circ} \mathrm{C}, \sim 2.4 \mathrm{wt} \% \mathrm{H}_{2}$ absorption is observed in $\sim 2 \mathrm{~h}$ under 50 bar $\mathrm{H}_{2}$ pressure [49]. Unfortunately, the theoretical $\mathrm{H}$ capacity of $2.95 \mathrm{wt} \% \mathrm{H}_{2}$ is not observed due to loss of $\mathrm{Na}$ and $\mathrm{Mg}$ during desorption.

$3 \mathrm{NaMgH}_{2} \mathrm{~F} \rightarrow \mathrm{NaMgF}_{3}+2 \mathrm{Na}_{(\mathrm{l})}+2 \mathrm{Mg}+3 \mathrm{H}_{2}$ 


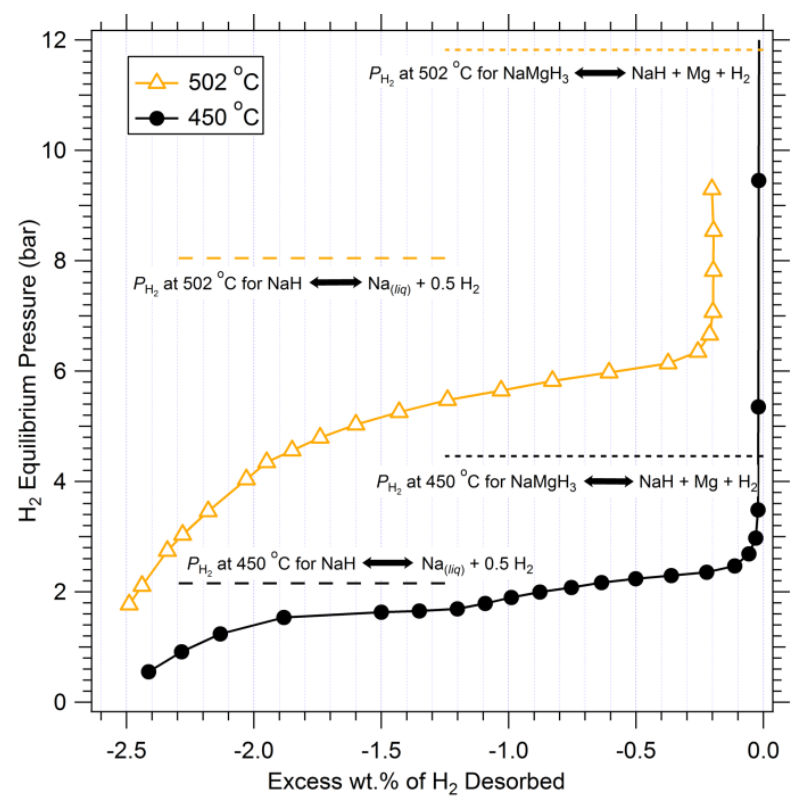

Fig. 5. Desorption $\mathrm{PCl}$ measurements for $\mathrm{NaMgH}_{2} \mathrm{~F}$. As a comparison, dashed lines indicate the $\mathrm{H}_{2}$ desorption equilibrium pressure for $\mathrm{NaMgH}_{3}$ and $\mathrm{NaH}$ at equivalent temperatures.

$\mathrm{NaMgH}_{2} \mathrm{~F}$ has been cycled at $500{ }^{\circ} \mathrm{C}$ and exhibited poor stability with only $31 \%$ of the initial $\mathrm{H}_{2}$ capacity retained compared to $\mathrm{NaMgH}_{3}$ that retained $73 \%$ of its initial capacity after 10 cycles [25]. If the distillation of $\mathrm{Na}$ and $\mathrm{Mg}$ [10] can be addressed, $\mathrm{NaMgH}_{2} \mathrm{~F}$ holds potential as a TES due to the low cost of the raw material and increased operating temperatures compared to other prospective $\mathrm{HTMHs}$ (Table 1). The higher enthalpy of $\mathrm{H}_{2}$ absorption by $\mathrm{NaMgH}_{2} \mathrm{~F}$ also reduces the amount of $\mathrm{H}_{2}$ required in the system that in turn reduces the overall mass and cost of the LTMH. One aspect that must be overcome is the loss of $\mathrm{Mg}$ and $\mathrm{Na}$ during decomposition.

\section{Sodium-based complex transition metal hydrides}

Considering the scope of complex transition metal hydrides that have been characterised since the $1970 \mathrm{~s}[1,2]$ there is a distinct absence of Na-based complex transition metal hydrides and, of those that are known, many have a not had their thermodynamic properties determined. As such, this section provides an overview of the known Na-based complex transition metal hydrides, while also describing their known thermodynamic properties or comparing them to analogous complexes of the identical transition metal hydride centre. The synthesis conditions and subsequent crystallographic properties of each compound described are consolidated in Table 2.

Table 2: Na-based Complex Transition Metal hydrides

\begin{tabular}{|c|c|c|c|c|}
\hline Compound & $\begin{array}{c}\text { Theoretical } \\
\text { Gravimetric } \mathrm{H}_{2} \\
\text { content (wt\%) }\end{array}$ & $\begin{array}{l}\text { Crystallographic } \\
\text { space group }\end{array}$ & Synthesis conditions & $\begin{array}{l}\text { Decomposition } \\
\text { Temperature }\left({ }^{\circ} \mathrm{C}\right)\end{array}$ \\
\hline $\mathrm{Na}_{2} \mathrm{Mg}_{2} \mathrm{FeH}_{8}[3]$ & 5.09 & Pbam & $400^{\circ} \mathrm{C}, 300$ bar $\mathrm{H}_{2}$ & 400 \\
\hline $\mathrm{Na}_{2} \mathrm{Mg}_{2} \mathrm{NiH}_{6}[56,57]$ & 3.80 & Pnma & $300-315^{\circ} \mathrm{C}, 50$ bar $\mathrm{H}_{2}$ & Unknown \\
\hline $\mathrm{Na}_{2} \mathrm{Mg}_{2} \mathrm{RuH}_{8}[3]$ & 4.00 & Pbam & $500^{\circ} \mathrm{C}, 300$ bar $\mathrm{H}_{2}$ & 421 \\
\hline $\mathrm{Na}_{3} \mathrm{RuH}_{7}[58]$ & 3.98 & $P 4_{2} / m n m$ & $597^{\circ} \mathrm{C}, 5000$ bar $\mathrm{H}_{2}$ & Unknown \\
\hline $\mathrm{Na}_{4} \mathrm{RuH}_{6}[59]$ & 3.04 & $R 3 c$ & $480^{\circ} \mathrm{C}, 10$ bar $\mathrm{H}_{2}$ & Unknown \\
\hline $\mathrm{Na}_{3} \mathrm{OsH}_{7}[58]$ & 2.65 & $P 4_{2} / \mathrm{mnm}$ & $597^{\circ} \mathrm{C}, 1500$ bar $\mathrm{H}_{2}$ & Unknown \\
\hline $\mathrm{Na}_{3} \mathrm{RhH}_{6}[2]$ & 3.40 & Pnma & $387-497^{\circ} \mathrm{C}$, under $\mathrm{H}_{2}$ & unknown \\
\hline $\mathrm{Na}_{3} \mathrm{IrH}_{6}[2]$ & 2.26 & Pnma & $387-497^{\circ} \mathrm{C}$, under $\mathrm{H}_{2}$ & unknown \\
\hline $\mathrm{Na}_{2} \mathrm{PdH}_{4}[60]$ & 2.58 & $14 / \mathrm{mmm}$ & $497^{\circ} \mathrm{C}, 1800$ bar $\mathrm{H}_{2}$ & $>327^{\circ} \mathrm{C}$ and 1 bar $\mathrm{H}_{2}$ \\
\hline $\mathrm{NaBaPdH}_{3}[61]$ & 1.12 & $P 63 / m m c$ & $510^{\circ} \mathrm{C}, 90$ bar $\mathrm{H}_{2}$ & unknown \\
\hline $\mathrm{Na}_{2} \mathrm{PdH}_{2}[2,62]$ & 1.31 & $14 / \mathrm{mmm}$ & $370^{\circ} \mathrm{C}, 1$ bar $\mathrm{H}_{2}$ & 408 (melt) \\
\hline $\mathrm{Na}_{2} \mathrm{PtH}_{4}[63]$ & 1.65 & $14 / \mathrm{mmm}$ & $280-310^{\circ} \mathrm{C}, 1$ bar $\mathrm{H}_{2}$ & unknown \\
\hline
\end{tabular}

The stability of the transition metal centre is the main contributing factor for the dearth of Na-based complex transition metal hydrides [64]. For instance, most of the $3 d$ transition metals that do form complex transition metal 
hydride anions are known only to be coordinated by di- or trivalent countercations. One method to circumvent this conundrum is to increase the anionic charge of the system, for instance by the inclusion of $\mathrm{H}^{-}$, which in turn enables tuning of these materials in order to optimise their thermodynamic properties or hydrogen storage capacities [65]. Two recent examples of this is the formation of $\mathrm{Na}_{2} \mathrm{Mg}_{2} \mathrm{FeH}_{8}\left(2 \mathrm{Na}^{2+} \cdot 2 \mathrm{Mg}^{2+} \cdot 2 \mathrm{H}^{-} \cdot\left[\mathrm{FeH}_{6}\right]^{4-}\right)[3,66]$ and $\mathrm{Na}_{2} \mathrm{Mg}_{2} \mathrm{NiH}_{6}$ $\left(2 \mathrm{Na}^{2+} \cdot 2 \mathrm{Mg}^{2+} \cdot 2 \mathrm{H}^{-} \cdot\left[\mathrm{NiH}_{4}\right]^{4-}\right)[56,57] . \mathrm{Na}_{2} \mathrm{Mg}_{2} \mathrm{FeH}_{8}$ has been demonstrated to have increased stability in comparison to $\mathrm{Mg}_{2} \mathrm{FeH}_{6}$, the latter has a $\mathrm{H}_{2}$ desorption maxima at $360{ }^{\circ} \mathrm{C}$ compared to $400{ }^{\circ} \mathrm{C}$ for $\mathrm{Na}_{2} \mathrm{Mg}_{2} \mathrm{FeH}_{8}$ [66]. $\mathrm{PCl}$ experiments also determine this material to decompose in three stages (Eq. 4-6), via $\mathrm{NaMgH}_{3}$ and $\mathrm{NaH}$. The first stage occurs at 55 bar $\mathrm{H}_{2}$ at $360{ }^{\circ} \mathrm{C}$ and has an associated $\Delta H_{\text {des }}=93 \mathrm{~kJ} \cdot \mathrm{mol}^{-1} \mathrm{H}_{2}$, while the second stage occurs at 0.5 bar $\mathrm{H}_{2}\left(360{ }^{\circ} \mathrm{C}\right.$, $\left.\Delta H_{\text {des }}=87 \mathrm{~kJ} \cdot \mathrm{mol}^{-1} \mathrm{H}_{2}\right)$, whereas the final stage occurs at 0.1 bar $\mathrm{H}_{2}\left(360^{\circ} \mathrm{C}, \Delta H_{\text {des }}=111 \mathrm{~kJ} \cdot \mathrm{mol}^{-1} \mathrm{H}_{2}\right)$. Overall, the feasibility of cycling and technological use of this system is limited due to the pressures required for the synthesis of $\mathrm{Na}_{2} \mathrm{Mg}_{2} \mathrm{FeH}_{8}$ (300 bar, Table 2), but the fact that decomposition proceeds via its synthesis route, with no other intermediates, makes this system potentially viable. Although the thermal properties of $\mathrm{Na}_{2} \mathrm{Mg}_{2} \mathrm{NiH}_{6}$ have not yet been ascertained, it is anticipated that the complex will gain extra stability in comparison to $\mathrm{Mg}_{2} \mathrm{NiH}_{4}$ which decomposes at $325^{\circ} \mathrm{C}$ under 21 bar of $\mathrm{H}_{2}$ pressure [67].

$$
\begin{array}{ll}
\mathrm{Na}_{2} \mathrm{Mg}_{2} \mathrm{FeH}_{8} \rightarrow 2 \mathrm{NaMgH}_{3}+\mathrm{Fe}+\mathrm{H}_{2} & \text { (1.3wt\%) } \\
2 \mathrm{NaMgH}_{3}+\mathrm{Fe} \rightarrow 2 \mathrm{NaH}+2 \mathrm{Mg}+2 \mathrm{H}_{2}+\mathrm{Fe} & (2.5 \mathrm{wt} \%) \\
2 \mathrm{NaH}+2 \mathrm{Mg}+\mathrm{Fe} \rightarrow 2 \mathrm{Na}+2 \mathrm{Mg}+\mathrm{Fe}+\mathrm{H}_{2} & (1.3 \mathrm{wt} \%)
\end{array}
$$

The transition to $4 d$ and $5 d$ metals vastly increases the array of potential candidates for energy storage materials, although the cost of the materials also dramatically increases [1-3]. This is reflected in the limited thermodynamic investigations that have been carried out on the structurally characterised complex metal hydrides. Ru has the greatest number of characterised materials, of which only one, $\mathrm{Na}_{2} \mathrm{Mg}_{2} \mathrm{RuH}_{8}$, has been studied in any depth. $\mathrm{PCl}$ measurements have determined thermal decomposition to occur in a two-step process via the formation of $\mathrm{Mg}_{2} \mathrm{RuH}_{4}$ to $\mathrm{Mg}_{3} \mathrm{Ru}_{2}, \mathrm{Na}$ and $\mathrm{H}_{2}$ under 0.5 bar $\mathrm{H}_{2}$ pressure at $450{ }^{\circ} \mathrm{C}$ (Eq. 7-8) [66]. The enthalpies of decomposition associated with these events are $131 \mathrm{~kJ} \cdot \mathrm{mol}^{-1} \mathrm{H}_{2}$ for step one and $119 \mathrm{~kJ} \cdot \mathrm{mol}^{-1} \mathrm{H}_{2}$ for the second. The overall enthalpy of decomposition is $125 \mathrm{~kJ} \cdot \mathrm{mol}^{-1} \mathrm{H}_{2}$. Decomposition under reduced pressure allows for the onset of decomposition to occur at ca. $325^{\circ} \mathrm{C}$, with the first maxima being observed at ca. $421{ }^{\circ} \mathrm{C}$, and the second at ca. 460 ${ }^{\circ} \mathrm{C}$. Cycling of this material has not been conducted although the pressures of 300 bar required for full synthesis of $\mathrm{Na}_{2} \mathrm{Mg}_{2} \mathrm{RuH}_{8}$ will inhibit technological application but partial hydrogenation to $\mathrm{Mg}_{2} \mathrm{RuH}_{4}$ (isolated under pressure) may be of interest.

$$
\begin{aligned}
& \mathrm{Na}_{2} \mathrm{Mg}_{2} \mathrm{RuH}_{8} \rightarrow 2 \mathrm{Na}+\mathrm{Mg}_{2} \mathrm{RuH}_{4}+2 \mathrm{H}_{2} \quad\left(2.0 \mathrm{wt} \% \mathrm{H}_{2}\right) \\
& \mathrm{Mg}_{2} \mathrm{RuH}_{4}+2 \mathrm{Na} \rightarrow \mathrm{Mg}_{3} \mathrm{Ru}_{2}+2 \mathrm{Na}+2 \mathrm{H}_{2} \quad\left(2.0 \mathrm{wt} \% \mathrm{H}_{2}\right)
\end{aligned}
$$

Other structurally characterised group 8 transition metal hydrides include $\mathrm{Na}_{3} \mathrm{RuH}_{7}$ and the analogous $\mathrm{Na}_{3} \mathrm{OsH}_{7}$ [58]. Although the decomposition of these materials has not been studied, the analogous compound, $\mathrm{LiMg}_{2} \mathrm{RuH}_{7}$, decomposes to $\mathrm{Mg}_{2} \mathrm{RuH}_{6}+\mathrm{LiH}$ at $570-580^{\circ} \mathrm{C}$ under a $\mathrm{H}_{2}$ pressure of $\sim 70$ bar [68]. Although the $\mathrm{Na}_{3} \mathrm{FeH}_{7}$ analogue has not been synthesised, a recent DFT study investigating the electronic structure of $\mathrm{Na}_{3} \mathrm{RuH}_{7}$ has predicted that the formation of $\mathrm{Li}_{3} \mathrm{FeH}_{7}$ is feasible with an associated enthalpy change of $-16 \mathrm{~kJ} \cdot \mathrm{mol}^{-1} \mathrm{H}_{2}$ for the hydrogenation of $3 \mathrm{LiH}+$ Fe [69]. Further examples of the flexible coordination of the ruthenium hydride anions [64] is the formation of $\mathrm{Na}_{4} \mathrm{RuH}_{6}$ and $\mathrm{Li}_{4} \mathrm{RuH}_{6}$. Unfortunately, no thermodynamic studies have been conducted on these materials, although further studies of $\mathrm{Li}_{4} \mathrm{RuH}_{6}$ have been carried out by means of first-principles calculations and vibrational spectroscopy [70]. The lack of physical information on these compounds (and the following materials) is likely due to the cost of the raw materials which not only inhibits technological applications but also the ability to perform accurate thermodynamic measurements (due to the quantities of materials required). 
The $\mathrm{Na}$-based hexa-hydride complexes of $\mathrm{Rh}$ and $\mathrm{Ir}\left(\mathrm{Na}_{3} \mathrm{RhH}_{6}\right.$ and $\left.\mathrm{Na}_{3} \mid \mathrm{rH}_{6}\right)$ were first reported in 1991 [2]. Unfortunately, thermal studies on these compounds stretch as far as acknowledging that there is no structural phase transition in the temperature range of $-262{ }^{\circ} \mathrm{C}$ and $397{ }^{\circ} \mathrm{C}$ for $\mathrm{Na}_{3} \mathrm{RhH}_{6}$ or $\mathrm{Na}_{3} / \mathrm{rH}_{6}$. Some further theoretical studies have been conducted as to determine the electronic structure of ternary rhodium hydrides, although no thermodynamics or stabilities were eluded to [71].

Since 1988 there have been a variety of $\mathrm{Na}$-based $\mathrm{Pd}$ and $\mathrm{Pt}$ hydrides reported in the literature. $\mathrm{Na}_{2} \mathrm{PdH}_{2}$ is a brittle solid and has been reported to melt without decomposing at $408^{\circ} \mathrm{C}[2,62]$, although little work has been conducted on the thermal properties of this compound or the analogous $\mathrm{CaPdH}_{2}$ [72]. $\mathrm{Na}_{2} \mathrm{PdH}_{4}$ has been determined to decompose into $\mathrm{Na}_{2} \mathrm{PdH}_{2}$ at temperatures of $>327^{\circ} \mathrm{C}$ and 1 bar $\mathrm{H}_{2}$, while on the contrary, other alkali metal [ $\left[\mathrm{PdH}_{4}\right]^{2-}$ complexes, such as $\mathrm{Rb}_{2} \mathrm{PdH}_{4}$ will cycle between $\mathrm{Rb}_{2} \mathrm{PdH}_{4}, \mathrm{Rb}_{3} \mathrm{PdH}_{5}$ and $\mathrm{Rb}_{3} \mathrm{PdH}_{3}$ [73]. One Na-based compound of $\mathrm{Pt}$ is also known. $\mathrm{Na}_{2} \mathrm{PtH}_{4}$ is isotypic with that of $\mathrm{Na}_{2} \mathrm{PdH}_{4}$, although no thermodynamic properties have been established.

\section{5. $\mathrm{NaBH}_{4}$}

Sodium borohydride, $\mathrm{NaBH}_{4}$, is an air stable hydride that is widely used as a powerful reducing agent in both organic and inorganic chemistry [45]. It is produced on an industrially scale of $2000-3000$ ton annually via the BrownSchlesinger process [44] (Eq. 9), but can alternatively be synthesised via the Bayer method [74, 75] (Eq. 10)

$$
\begin{aligned}
& \mathrm{B}\left(\mathrm{OCH}_{3}\right)_{3}+4 \mathrm{NaH} \rightarrow \mathrm{NaBH}_{4}+3 \mathrm{NaOCH}_{3} \quad\left(250-270{ }^{\circ} \mathrm{C}\right) \\
& \mathrm{Na}_{2} \mathrm{~B}_{4} \mathrm{O}_{7}+16 \mathrm{Na}+8 \mathrm{H}_{2}+7 \mathrm{SiO}_{2} \rightarrow 4 \mathrm{NaBH}_{4}+7 \mathrm{Na}_{2} \mathrm{SiO}_{3} \quad\left(700^{\circ} \mathrm{C}\right)
\end{aligned}
$$

Sodium borohydride shows interesting potential as a high temperature thermal energy storage system due to its high theoretical hydrogen content of $10.7 \mathrm{wt} \%$ and a high thermodynamic stability. Decomposition has been demonstrated to occur slowly under vacuum at $400{ }^{\circ} \mathrm{C}$ while $\mathrm{NaBH}_{4}$ begins to melt between $505{ }^{\circ} \mathrm{C}$ and $510{ }^{\circ} \mathrm{C}[45$, $76,77]$ with near simultaneous decomposition and hydrogen release via:

$$
\mathrm{NaBH}_{4} \rightarrow \mathrm{Na}_{(l)}+\mathrm{B}+2 \mathrm{H}_{2(\mathrm{~g})}
$$

Mass spectrometry measurements performed during $\mathrm{NaBH}_{4}$ decomposition showed undetectable levels of $\mathrm{B}_{2} \mathrm{H}_{6}$ in the $\mathrm{H}_{2}$ stream $[77,78]$, while in situ XRD indicates that no crystalline phases are formed during decomposition [79]. This is contrary to other borohydrides, including $\mathrm{LiBH}_{4}, \mathrm{Mg}\left(\mathrm{BH}_{4}\right)_{2}, \mathrm{Zn}\left(\mathrm{BH}_{4}\right)_{2}$ and $\mathrm{Eu}\left(\mathrm{BH}_{4}\right)_{2}$, that actively form borane complexes such as $\mathrm{B}_{2} \mathrm{H}_{6},\left[\mathrm{~B}_{3} \mathrm{H}_{8}\right]^{-},\left[\mathrm{B}_{10} \mathrm{H}_{10}\right]^{2-}$ and $\left[\mathrm{B}_{12} \mathrm{H}_{12}\right]^{2-}[80-84]$ that inhibits reversible hydrogenation and hence technological application of these materials. To date, the only known report of $\mathrm{Na}_{2} \mathrm{~B}_{12} \mathrm{H}_{12}$ formation during decomposition of $\mathrm{NaBH}_{4}$ was by ${ }^{11} \mathrm{~B}$ MAS NMR spectroscopy of decomposed $\mathrm{NaBH}_{4}$ infiltrated into nanoporous carbon [85]. The article also noted that $\mathrm{Na}_{2} \mathrm{~B}_{12} \mathrm{H}_{12}$ was formed during the dehydrogenation of bulk $\mathrm{NaBH}_{4}$, along with a measured release of $8.1 \mathrm{wt} \% \mathrm{H}$. While the maximum theoretical $10.7 \mathrm{wt} \% \mathrm{H}$ was not obtained, it may suggest that $\mathrm{Na}_{2} \mathrm{~B}_{12} \mathrm{H}_{12}$ may be a decomposition intermediate, which may be amorphous during decomposition. During this particular experiment, the bulk $\mathrm{NaBH}_{4}$ was heated at the maximum temperature of $600{ }^{\circ} \mathrm{C}$ before cooling. This implies that $\mathrm{Na}_{2} \mathrm{~B}_{12} \mathrm{H}_{12}$ should not be an intermediate and it is extraordinary that it has not been observed before.

The high hydrogen capacity and high thermal stability $\left(\Delta H_{\text {des }}=100.4-108.3 \mathrm{~kJ} \cdot \mathrm{mol}^{-1} \mathrm{H}_{2}\right.$ and $\Delta S_{a b s}=128-133$ $\left.\mathrm{J} \cdot \mathrm{K}^{-1} \cdot \mathrm{mol}^{-1} \mathrm{H}_{2}[33,86]\right)$ of $\mathrm{NaBH}_{4}$ means that the theoretical gravimetric heat storage capacity of $\mathrm{NaBH}_{4}$ is an impressive $5307 \mathrm{~kJ} \cdot \mathrm{kg}^{-1}$. As far as the authors are aware, this value is only exceeded by the theoretical values for $\mathrm{LiH}$ $\left(8397 \mathrm{~kJ}^{\mathrm{kg}}{ }^{-1}\right.$ ) which requires operational temperatures of $\sim 1000{ }^{\circ} \mathrm{C}[33,36]$. While the thermodynamics of hydrogen release from $\mathrm{NaBH}_{4}$ have been measured, relatively little work has been conducted on its reversibility. The formation of $\mathrm{NaBH}_{4}$ by hydrogenation of its decomposition products, and also of a $\mathrm{NaH}$ and $\mathrm{B}$ mixture, has been demonstrated only in tandem with the infiltration of $\mathrm{NaBH}_{4}$ in to nanoporous carbon or inclusion of additives $[77,85,87]$. Solution infiltration not only decreases the onset temperature of decomposition to below $250{ }^{\circ} \mathrm{C}$, with a maximum decomposition of $\mathrm{H}_{2}$ at $350{ }^{\circ} \mathrm{C}$ (total $6.7 \mathrm{wt} \% \mathrm{H}$ ), but also facilitates the rehydrogenation of the products [85]. A 
maximum of $43 \%$ of the initial $\mathrm{H}_{2}$ capacity was recharged at relatively mild conditions of 60 bar $\mathrm{H}_{2}$ and $325{ }^{\circ} \mathrm{C}$. Meanwhile, a mixture of $\mathrm{NaH}$ and $\mathrm{B}$ ball milled with Ti additives allowed absorption of $5.1 \mathrm{wt} \% \mathrm{H}$ over 200 mins at $500{ }^{\circ} \mathrm{C}$ under 55 bar of $\mathrm{H}_{2}$ pressure. However, due to the fact that the starting materials are not representative of the decomposition products, this is not prototypical of a practical cycling scenario. Further studies of $\mathrm{NaBH}_{4}$ with various additives (nano particles, transition metal chlorides/fluorides and mesoporous materials) demonstrated that certain additives can destabilise, or alternatively stabilise $\mathrm{NaBH}_{4}$, while further cycling studies of $\mathrm{NaBH}_{4}$ with various $\mathrm{Ni}$ based additives detailed the fate of the additives [77]. This study determined that rehydrogenation is unattainable at 100 bar $\mathrm{H}_{2}$ at $430{ }^{\circ} \mathrm{C}$ and documented that $\mathrm{NaH}$ was the only hydrogenated product. At these high temperatures and pressures, $\mathrm{NaH}$ is the thermodynamically stable entity and, as discussed in Section 2, its presence hinders further hydrogenation.

To be integrated as part of a TES in CSP, $\mathrm{NaBH}_{4}$ would require operation at temperatures above $500{ }^{\circ} \mathrm{C}$. This infers that the cycling of $\mathrm{NaBH}_{4}$ must be conducted in the molten phase, although to date, no absorption measurements have been performed on molten $\mathrm{Na}$ and $\mathrm{B}$ mixtures above the melting point of $\mathrm{NaBH}_{4}$. One obvious difficulty of utilising $\mathrm{NaBH}_{4}$ above its melting point arises from both the volatility and high surface tension of molten sodium [88, 89]. When molten Na vaporises during decomposition, it agglomerates and segregates from the other reaction products: both of which lead to reduced or limited reversibility.

\section{Thermal Storage in Sodium-Based Aluminium Hexahydrides: $\mathrm{Na}_{3} \mathrm{AlH}_{6}, \mathrm{Na}_{2} \mathrm{LiAlH}_{6}$ and $\mathrm{K}_{2} \mathrm{NaAlH}_{6}$}

The class of complex hydrides known as alanates are comprised of tetrahedral $\left[\mathrm{AlH}_{4}\right]^{-}$or octahedral $\left.[\mathrm{AlH}]^{3-}\right]^{3-}$ anions coordinated by alkali metal counter-cations. These materials have been known since the 1940's with the original synthesis of $\mathrm{LiAlH}_{4}$ being reported in 1947 [90], while $\mathrm{NaAlH}_{4}$ [91] and $\mathrm{Na}_{3} \mathrm{AlH}_{6}$ [92] were not reported until the 1960 's. Since then, the decomposition process of $\mathrm{NaAlH}_{4}$ has been determined to be in three steps via $\mathrm{Na}_{3} \mathrm{AlH}_{6}($ Eqs. 12-14) although the process was not reversible under more moderate conditions until 1997 [93]. This was achieved by the addition of a suitable titanium-based catalyst and since multiple investigations have been undertaken into this process [34, 94-103]. Binary alkali aluminium hexahydrides (SBHs Category I) decompose via a very similar pathway (Eq. 15) and similar to $\mathrm{Na}_{3} \mathrm{AlH}_{6}$, reversible hydrogen absorption was subsequently shown to occur for pure $\mathrm{K}_{2} \mathrm{NaAlH}_{6}$ albeit very slowly [40]. The addition of Ti-based catalysts were also shown to enhance the rehydrogenation process [35].

$3 \mathrm{NaAlH}_{4} \rightleftarrows \mathrm{Na}_{3} \mathrm{AlH}_{6}+2 \mathrm{Al}+3 \mathrm{H}_{2}$

$\mathrm{Na}_{3} \mathrm{AlH}_{6}+\mathrm{Al} \rightleftarrows 3 \mathrm{NaH}+2 \mathrm{Al}+{ }^{3} / 2 \mathrm{H}_{2}$

$3 \mathrm{NaH}+2 \mathrm{Al} \rightleftarrows 3 \mathrm{Na}+2 \mathrm{Al}+3 / 2 \mathrm{H}_{2}$

$M_{2} \mathrm{M}^{\prime} \mathrm{AlH}_{6} \rightleftarrows 2 \mathrm{MH}+\mathrm{M}^{\prime} \mathrm{H}+\mathrm{Al}+{ }^{3} /{ }_{2} \mathrm{H}_{2}$

(Where $M=\mathrm{K}$ or $\mathrm{Na}$ and $M^{\prime}=\mathrm{Na}$ or $\mathrm{Li}$ )

Each of the hexahydride systems has a modest hydrogen capacity in comparison to other complex hydrides (Table 1) currently being explored for hydrogen storage in mobile applications $\left(\mathrm{Na}_{3} \mathrm{AlH}_{6}=2.96\right.$ wt\% $\mathrm{H}_{2}, \mathrm{Na}_{2} \mathrm{LiAlH}_{6}=3.52$ wt\% $\mathrm{H}_{2}, \mathrm{~K}_{2} \mathrm{NaAlH}_{6}=2.25 \mathrm{wt} \% \mathrm{H}_{2}$ ) and so comparatively little research on them has been undertaken. Despite this, the thermodynamics of hydrogen desorption in $\mathrm{Na}_{3} \mathrm{AlH}_{6}$ and $\mathrm{Na}_{2} \mathrm{LiAlH}_{6}$ have been investigated [39, 40, 93] and an increase from $\mathrm{Na}_{3} \mathrm{AlH}_{6}\left(\Delta H_{\text {des }}=47.4 \mathrm{JJ} \cdot \mathrm{mol}^{-1} \mathrm{H}_{2}, \Delta S_{\text {des }}=126.1 \mathrm{~J} \cdot \mathrm{K}^{-1} \cdot \mathrm{mol}^{-1} \mathrm{H}_{2}\right)$ to $\mathrm{Na}_{2} \mathrm{LiAlH}_{6}\left(\Delta H_{\text {des }}=55.0^{*} \mathrm{~kJ} \cdot \mathrm{mol}^{-1} \mathrm{H}_{2}\right.$, $\Delta S_{\text {des }}=135.0^{*} \mathrm{~J} \cdot \mathrm{K}^{-1} \cdot \mathrm{mol}^{-1} \mathrm{H}_{2}$, where ${ }^{*}=$ the average of refs [39] and [40]) upon substitution of one sodium for lithium. These values are similar to traditional intermetallic hydrides such as LaNi $\mathrm{Li}_{4.25} \mathrm{Al}_{0.75}\left(\Delta \mathrm{H}_{\text {des }}=44.1 \mathrm{~kJ} \cdot \mathrm{mol}^{-1} \mathrm{H}_{2}, \Delta S_{\text {des }}=117\right.$ $\left.\mathrm{J} \cdot \mathrm{K}^{-1} \cdot \mathrm{mol}^{-1} \mathrm{H}_{2}\right)[104]$, and $\mathrm{ZrMn}_{2}\left(\Delta H_{\text {des }}=53.2 \mathrm{~kJ} \cdot \mathrm{mol}^{-1} \mathrm{H}_{2}, \Delta S_{\text {des }}=121 \mathrm{~J} \cdot \mathrm{K}^{-1} \cdot \mathrm{mol}^{-1} \mathrm{H}_{2}\right)[105,106]$.

Studies on the thermodynamics of the $\mathrm{K}_{2} \mathrm{NaAlH}_{6}$ system are scarce but have been determined [35, 40]. The theoretical $\mathrm{H}_{2}$ capacity based on Eq. 15 is $2.25 \mathrm{wt} \%$, although the practical capacity is between $2.0 \mathrm{wt} \%$ and $2.2 \mathrm{wt} \%$ $[35,40]$. In the pure $\mathrm{K}_{2} \mathrm{NaAlH}_{6}$ system, a sloping absorption isotherm was measured at $300{ }^{\circ} \mathrm{C}$ due to slow kinetics, while a flat desorption plateau was observed at $325^{\circ} \mathrm{C}$ in $\mathrm{K}_{2} \mathrm{NaAlH}_{6}$ doped with 1 mol.\% $\mathrm{TiF}_{3}$ [35]. This suggests that 
a Ti-based catalyst is necessary to achieve reasonable kinetics and $\Delta H_{\text {des }}$ measured for such a sample was determined to be $98 \pm 2 \mathrm{~kJ} \cdot \mathrm{mol}^{-1} \mathrm{H}_{2}$. This translates to a theoretical gravimetric heat storage capacity of $1095 \mathrm{~kJ}^{\mathrm{kg}} \mathrm{kg}^{-1}$ and suggests that $\mathrm{K}_{2} \mathrm{NaAlH}_{6}$ may be of interest for TES systems. However, a number of unusual characteristics have been identified in this system that requires further investigation: (1) the entropy of desorption is unusually high $\left(150 \pm 4 \mathrm{~J} \cdot \mathrm{K}^{-1} \cdot \mathrm{mol}^{-1}\right.$ $\mathrm{H}_{2}$ ) and; (2) there is also evidence of the formation of molten phases upon decomposition [35].

The commercial viability of intermetallic hydrides for heat storage operating above $100{ }^{\circ} \mathrm{C}$, including thermally driven temperature-upgrading and thermally driven heat upgrading applications have so far been hindered due to plateau slope, hysteresis, low $\mathrm{H}_{2}$ capacity and high cost. Many of these problems have been addressed by these three sodium-based aluminium hexahydrides and they may be of interest for chemical industries that require heat at temperatures in the $150-400{ }^{\circ} \mathrm{C}$ range and agricultural food industries that require temperatures of up to $150{ }^{\circ} \mathrm{C}$ [19]. However, a number of important properties of $\mathrm{Na}$-based aluminium hexahydrides still need to be characterised before their commercial viability for the applications outlined above, can be determined. This includes assessing their cyclic stability over thousands of cycles (as of $2009 \mathrm{NaAlH}_{4}$ had been cycled up to 100 times [96, 107]) and assessing the intrinsic $\mathrm{H}_{2}$ absorption/desorption kinetics of $\mathrm{Na}_{2} \mathrm{LiAlH}_{6}$ and $\mathrm{K}_{2} \mathrm{NaAlH}_{6}$ [108]. Research on the cycling of $\mathrm{Na}_{3} \mathrm{AlH}_{6}$ doped with Ti-catalysts $[96,107,109]$ has shown that the $\mathrm{H}_{2}$ capacity is relatively stable at $\sim 1.7$ wt\% over 100 cycles (temperature of $170{ }^{\circ} \mathrm{C}$ and $\mathrm{H}_{2}$ pressure of $30-40 \mathrm{bar}$ ) when the absorption time is $1.75 \mathrm{~h}$ but that the cyclical $\mathrm{H}_{2}$ capacity improves if either the absorption time or temperature is increased $[103,109]$. The addition of 10 wt\% excess $\mathrm{Al}$ (and $10 \mathrm{wt} \%$ Expanded Natural Graphite) to Ti-catalysed $\mathrm{Na}_{3} \mathrm{AlH}_{6}$, cycled 150 times at $150^{\circ} \mathrm{C}$, has been shown to improve the reversible capacity [110]. This is, presumably, a result of the excess Al helping to circumvent the limited mass diffusion coefficients of the elements present. The cyclic $\mathrm{H}_{2}$ capacity of Ti-catalysed $\mathrm{Na}_{2} \mathrm{LiAlH}_{6}$ has only been tested for 28 cycles and showed a relatively stable value of $2.2-2.3 \mathrm{wt} \%$ when $5.5 \mathrm{~h}$ absorption time was used at $200{ }^{\circ} \mathrm{C}$ [109]. Decomposed $\mathrm{K}_{2} \mathrm{NaAlH}_{6}$ readily reabsorbs $\mathrm{H}_{2}$ but it does not reach full capacity due to the molten state of the decomposition products [35] and so measurements of its cyclic stability have not been performed.

Of the three sodium-based alanate hexahydrides, $\mathrm{Na}_{3} \mathrm{AlH}_{6}$ has progressed furthest towards practical applications. A prototype hydrogen storage tank, designed to operate at a temperature of up to $200^{\circ} \mathrm{C}$ and a $\mathrm{H}_{2}$ pressure of 50 bar, was developed using a light-weight aluminium alloy and contained $\sim 0.2 \mathrm{~kg}$ of $\mathrm{Na}_{3} \mathrm{AlH}_{6}$ catalysed with 4 mol.\% $\mathrm{TiCl}_{3}$ [111]. Heat transfer was achieved with an extrusion moulded aluminium heat exchanger through which the heat transfer oil flowed. While the scale of hydride used in this work was modest, the focus was on the development and characterisation of the low-cost, low-weight aluminium alloy tank. The ultimate aim of this work is to take advantage of the lower operating pressure of $\mathrm{Na}_{3} \mathrm{AlH}_{6}$, compared to $\mathrm{NaAlH}_{4}$, to use the waste heat from a High-Temperature Proton Exchange Membrane (HT-PEM) fuel cell operating at $\sim 180^{\circ} \mathrm{C}$ to supply the necessary heat to release the $\mathrm{H}_{2}$ from $\mathrm{Na}_{3} \mathrm{AlH}_{6}$ which desorbs at $116{ }^{\circ} \mathrm{C}$ at 1 bar $\mathrm{H}_{2}\left(47 \mathrm{~kJ} \cdot \mathrm{mol}^{-1} \mathrm{H}_{2}\right)$ [96]. The experience gained in the processing, handling and development of hydrogen storage tanks utilising several kilograms of $\mathrm{NaAlH}_{4}$ [111-115] for hydrogen storage in mobile applications has been thoroughly explored and, as such, many of the issues involving heat transfer during cycling and safety concerns have been addressed, as such this research can readily be extended to the alanate hexahydrides.

\section{Safety Aspects}

A justified concern about using $\mathrm{Na} / \mathrm{NaH}$ for thermal energy storage on the scale required for CSP is its safety. Elemental $\mathrm{Na}$ and $\mathrm{NaH}$ have a number of unusual fire hazards. The auto ignition temperature of both $\mathrm{Na}$ and $\mathrm{NaH}$ in air is highly variable between $120^{\circ} \mathrm{C}$ and $470{ }^{\circ} \mathrm{C}$ and depends on factors (such as the initial temperature and surface area of the $\mathrm{Na} / \mathrm{NaH}$, atmospheric moisture levels and the rate of thermal dissipation to the surroundings [116]) and any leak of $\mathrm{Na}$ or $\mathrm{NaH}$ at temperatures relevant to CSP applications would result in auto ignition. Interestingly, the burning of $\mathrm{Na}$ is less energetic than equivalent hydrocarbon fires; sodium flames rarely attain a height of more than a few centimetres versus the potential of several metres above a liquid hydrocarbon fire [117]; the radiant heat in $\mathrm{Na}$ fires is substantially less than liquid hydrocarbon fires and the temperature may be as low as $100{ }^{\circ} \mathrm{C}$ at a height of 1 metre above a liquid $\mathrm{Na}$ pool compared to a temperature of more than $600{ }^{\circ} \mathrm{C}$ at a height of 2 metres above a 
gasoline fire [50]. The main danger associated with $\mathrm{Na}$ fires is vigorous emission of oxide fumes $\left(\mathrm{Na}_{2} \mathrm{O}\right)$, which upon contact with $\mathrm{H}_{2} \mathrm{O}$, rapidly reacts to produce caustic $\mathrm{NaOH}$.

The $110 \mathrm{MW}_{\text {el }}$ net (125 MWel gross) CSP plant constructed by Solar Reserve at Crescent Dunes can store $3335 \mathrm{MWh}$ of thermal energy using 32,000 tonnes molten salts [118]. To store an equivalent amount of thermal energy using $\mathrm{NaH}$ would require a mass of 4,473 tonnes $(4,285$ tonnes of $\mathrm{Na}$ ). It is noted that a historical precedent exists for the use and handling of high-temperature molten $\mathrm{Na}$ on this scale in the nuclear industry. The Superphénix liquid-metal fast-breeder reactor (LMFBR) operated between 1986 and 1996 in France used more than 5,000 tonnes of molten sodium as a coolant [43] while containment materials for molten sodium [119-122] and fire safety protocols [123126] have been devised over 50+ years of LMFBR development. Despite this, Na leaks and fires have occurred at fast breeder reactors but these have primarily been shown to be the result of human error in operation, design or fabrication [127]. An example of the successful use of molten sodium as a coolant is the Experimental Breeder Reactor-II (EBR-II) that operated for 30 years without any leaks [50]. There are also important differences between the use of molten Na in LMFBRs and Na-based hydrides for TES systems in CSP. These include:

- LMFBRs pump molten sodium at a rate of several metres per second [50] under pressure and a leak scenario is assumed to involve a stream or spray from a containment failure point that forms a pool of molten $\mathrm{Na}$ [123]. For most of the SBHs systems considered for CSP applications they exist as solid hydrides for half of the time and even if desorbed, the molten Na will wet the other dehydrogenation products. This means that in a containment failure situation, the hydrides are unlikely to flow in the same manner as for LMFBRs.

- Containment of molten sodium used in a dynamic environment, especially if a temperature gradient exists, is a challenge as the sodium flow promotes the dissolution of metallic elements from the containment material in hot regions and their deposition in cooler regions. This then leaves the molten sodium ready to dissolve more of the containment material during its next pass through the hot zone [43, 121].

- Lastly, densified hydride compacts (and their decomposition products) that would be used for CSP and heat pumping applications have been shown to be far less reactive than loose powders $[128,129]$. The degree to which this applies to dense hydride beds operating at high temperatures would need to be researched.

Though a significant amount of research has been done on the safe handling of molten sodium for use with LMFBRs, the different manner of use means that a significant amount of research still needs to be undertaken on the safety of high-temperature Na-based hydrides for TES in CSP systems.

\section{Outlook}

Sodium-based hydrides show promise as thermal energy storage systems and for heat pumping applications. However, there is a long path between the identification of promising hydrides and commercialisation. For sodiumbased hydrides belonging to Category I, such as $\mathrm{Na}_{3} \mathrm{AlH}_{6}, \mathrm{Na}_{2} \mathrm{LiAlH}_{6}, \mathrm{~K}_{2} \mathrm{NaAlH}_{6}$ and $\mathrm{NaMgH}_{3}$, there are knowledge gaps in their fundamental properties mainly centred around determining their intrinsic $\mathrm{H}_{2}$ kinetics and long term cyclic stability. For most sodium-based transition metal hydrides, the decomposition reactions and thermodynamics have not been determined. Sodium-based hydrides belonging to Category II, such as $\mathrm{NaH}, \mathrm{NaMgH}_{2} \mathrm{~F}$ and $\mathrm{NaBH}_{4}$, have significantly more challenges to address due to the low vapour pressure and hydriding difficulties of molten sodium. Even at this early stage of development, Category II sodium-based hydrides show potential to compete economically with current state-of-the-art molten nitrate salts as thermal energy storage systems for concentrating solar-thermal power and, if alternate sodium hydride production methods can be realised, the cost of these hydrides could be reduced by up to a factor or 10 [51].

Beyond determining the basic properties of SBHs, a significant amount of engineering research is required to ultimately determine their commercial viability. While a large body of knowledge exists for the safe handling and use of molten sodium on an industrial scale due to its long history of use as a coolant in liquid-metal fast-breeder reactors, this needs to be extended to account for the differences associated with the use of Category II sodiumbased hydrides for thermal energy storage in concentrated solar-thermal power.

\section{References}


1. K. Yvon, Chimia 52, 613 (1998)

2. K. Yvon, G. Renaudin, Hydrides: Solid State Transition Metal Complexes, (John Wiley \& Sons, Ltd, 2006),

3. T.D. Humphries, S. Takagi, G. Li, M. Matsuo, T. Sato, M.H. Sørby, S. Deledda, B.C. Hauback, S. Orimo, J. Alloys Compd. 645, S347 (2015)

4. H.W. Li, Y.G. Yan, S. Orimo, A. Zuttel, C.M. Jensen, Energies 4, 185 (2011)

5. S. Orimo, Y. Nakamori, J.R. Eliseo, A. Zuttel, C.M. Jensen, Chem. Rev. 107, 4111 (2007)

6. E. Roennebro, Curr. Opin. Solid State Mater. Sci. 15, 44 (2011)

7. R. Cerny, G. Severa, D.B. Ravnsbæk, Y. Filinchuk, V. D'Anna, H. Hagemann, D. Haase, C.M. Jensen, T.R. Jensen, J. Phys. Chem. C 114, 1357 (2010)

8. A. Bouamrane, C. de Brauer, J.P. Soulié, J.M. Létoffé, J.P. Bastide, Thermochim. Acta 326, 37 (1999)

9. A. Bouamrane, J.P. Laval, J.-P. Soulié, J.P. Bastide, Mater. Res. Bull. 35, 545 (2000)

10. D.A. Sheppard, C. Corgnale, B. Hardy, T. Motyka, R. Zidan, M. Paskevicius, C.E. Buckley, RSC Adv. 4, 26552 (2014)

11. D.A. Sheppard, M. Paskevicius, C.E. Buckley, Chem. Mater. 23, 4298 (2011)

12. S. Satyapal, J. Petrovic, G. Thomas, Sci. Am. 296, 80 (2007)

13. Q. Lai, M. Paskevicius, D.A. Sheppard, C.E. Buckley, A.W. Thornton, M.R. Hill, Q. Gu, J. Mao, Z. Huang, H.K. Liu, Z. Guo, A. Banerjee, S. Chakraborty, R. Ahuja, K.-F. Aguey-Zinsou, ChemSusChem 8, 2789 (2015)

14. M. Felderhoff, R. Urbanczyk, S. Peil, Green 3, 113 (2013)

15. C. Corgnale, B. Hardy, T. Motyka, R. Zidan, J. Teprovich, B. Peters, Renewable and Sustainable Energy Reviews 38, 821 (2014)

16. P. Dantzer, Metal-hydride technology: A Critical Review, In Hydrogen in Metals III, ed. by H. Wipf (SpringerVerlag, Heidelberg, Germany, 1997)

17. S. Suda, Int. J. Hydrogen Energy 12, 323 (1987)

18. G. Sandrock, S. Suda, L. Schlapbach, Applications, In Hydrogen in Intermetallic Compunds II, ed. by L. Schlapbach (Springer Berlin Heidelberg, 1992), p. 197-258

19. P. Dantzer, Mater. Sci. Eng., A 329-331, 313 (2002)

20. M.V. Lototskyy, V.A. Yartys, B.G. Pollet, R.C. Bowman, Int. J. Hydrogen Energy 39, 5818 (2014)

21. P. Dantzer, E. Orgaz, J. Chem. Phys. 85, 2961 (1986)

22. G. Sandrock, J.R.C. Bowman, J. Alloys Compd. 356-357, 794 (2003)

23. Metal Prices.com. http://www.metalprices.com/metal/magnesium/magnesium-99-9-usa, Accessed 31 August 2015

24. M. Golben, D.H. DaCosta, In Proceedings of the 2002 U.S. DOE Hydrogen Program Review, (U.S. Department of Energy, 2002), p. 5

25. P.A. Ward, C. Corgnale, J.A. Teprovich, T. Motyka, B. Hardy, B. Peters, R. Zidan, J. Alloys Compd. 645, S374 (2015)

26. D.N. Harries, M. Paskevicius, D.A. Sheppard, T. Price, C.E. Buckley, Proc. IEEE 100, 539 (2012)

27. M. Fellet, C.E. Buckley, M. Paskevicius, D.A. Sheppard, MRS Bulletin 38, 1012 (2013)

28. D.A. Sheppard, T.D. Humphries, C.E. Buckley, Mater. Today, dx.doi.org/10.1016/j.mattod.2015.08.003 (2015)

29. R.W. Bradshaw, N.P. Siegel, In Energy Sustainability, (ASME, Jacksonville, Florida, USA, 2008), p. 7

30. C. Turchi, M. Mehos, C.K. Ho, G.J. Kolb, (2010), NREL/CP-5500-49303

31. G. Kolb, C.K. Ho, T. Manchini, J. Gary, (2011), SAND2011-2419

32. SunShot Vision Study, Chapter 5: Concentrating Solar Power: Technologies, Cost, and Performance (US

Department of Energy, 2012)

33. Outukumpu, HSC Chemistry, (2006)

34. B. Bogdanovic, R.A. Brand, A. Marjanovic, M. Schwickardi, J. Tolle, J. Alloys Compd. 302, 36 (2000)

35. M.H. Sørby, H.W. Brinks, A. Fossdal, K. Thorshaug, B.C. Hauback, J. Alloys Compd. 415, 284 (2006)

36. F.D. Manchester, A. San-Martin, Phase Diagrams of Binary Hydrogen Alloys. (ASM International, Ohio, 2000),

37. A. Reiser, B. Bogdanovic, K. Schlichte, Int. J. Hydrogen Energy 25, 425 (2000)

38. B. Bogdanović, H. Hofmann, A. Neuy, A. Reiser, K. Schlichte, B. Spliethoff, S. Wessel, J. Alloys Compd. 292, 57 (1999)

39. A. Fossdal, H.W. Brinks, J.E. Fonnelop, B.C. Hauback, J. Alloys Compd. 397, 135 (2005)

40. J. Graetz, Y. Lee, J.J. Reilly, S. Park, T. Vogt, Phys. Rev. B 71, (2005)

41. D.M. Banus, J.J. McSharry, E.A. Sullivan, J. Am. Chem. Soc. 77, 2007 (1955)

42. W. Klostermeier, E.U. Franck, Ber. Bunsen-Ges. Phys. Chem. 86, 606 (1982)

43. T.B. Cochran, H.A. Feiveson, W. Patterson, G. Pshakin, M.V. Ramana, M. Schneider, T. Suzuki, F.v. Hippel, Fast Breeder Reactor Programs: History and Status, (2010)

44. H.I. Schlesinger, H.C. Brown, A.E. Finholt, J. Am. Chem. Soc. 75, 205 (1953)

45. P. Rittmeyer, U. Wietelmann, Hydrides, In Ullmann's Encyclopedia of Industrial Chemistry, (Wiley-VCH Verlag $\mathrm{GmbH} \&$ Co. KGaA, 2000) 
46. E. Wiberg, N. Wiberg, Inorganic Chemistry. (Academic Press, 2001)

47. V. Procházka, M. Nedvěd, Collect. Czech. Chem. Commun. 38, 2845 (1973)

48. J. Sŭbrt, P. Kříž, J. Skřivánek, V. Procházka, Collect. Czech. Chem. Commun., 3766 (1975)

49. Previously unpublished results

50. T. Fanning, Sodium as a fast reactor coolant, (Argonne National Laboratory, 3 May 2007),

51. J.P. DiPietro, E.G. Skolnik, In Proceedings of the 2000 DOE Hydrogen Program Review, (U.S. Department of Energy, 2000), p. 29

52. C.E. Messer, J. Solid State Chem. 2, 144 (1970)

53. H. Reardon, N. Mazur, D.H. Gregory, Prog. Nat. Sci. 23, 343 (2013)

54. D. Pottmaier, E.R. Pinatel, J.G. Vitillo, S. Garroni, M. Orlova, G.B.M. Vaughan, M. Fichtner, W. Lohstroh, M.

Baricco, 2, 2317 (2011)

55. K. Komiya, N. Morisaku, R. Rong, Y. Takahashi, Y. Shinzato, H. Yukawa, M. Morinaga, J. Alloys Compd. 453, 157

(2008)

56. M. Orlova, J.-P. Rapin, K. Yvon, Inorg. Chem. 48, 5052 (2009)

57. K. Kadir, D. Noréus, Inorg. Chem. 46, 3288 (2007)

58. W. Bronger, T. Sommer, G. Auffermann, P. Müller, J. Alloys Compd. 330-332, 536 (2002)

59. M. Kritikos, D. Noréus, A.F. Andresen, P. Fischer, J. Solid State Chem. 92, 514 (1991)

60. W. Bronger, G. Auffermann, Chem. Mater. 10, 2723 (1998)

61. M. Olofsson, M. Kritikos, D. Noréus, Inorg. Chem. 37, 2900 (1998)

62. D. Noréus, K.W. Tornroos, A. Borje, T. Szabo, W. Bronger, H. Spittank, G. Auffermann, P. Muller, J. Less-Common Met. 139, 233 (1988)

63. W. Bronger, P. Müller, D. Schmitz, H. Spittank, Z. Anorg. Allg. Chem. 516, 35 (1984)

64. T.D. Humphries, D.A. Sheppard, C.E. Buckley, Chem. Commun. 51, 11248 (2015)

65. S. Takagi, T.D. Humphries, K. Miwa, S. Orimo, Appl. Phys. Lett. 104, 203901 (2014)

66. T.D. Humphries, M. Matsuo, G. Li, S.-i. Orimo, Phys. Chem. Chem. Phys. 17, 8276 (2015)

67. J.J. Reilly, R.H. Wiswall, Inorg. Chem. 7, 2254 (1968)

68. B. Huang, K. Yvon, P. Fischer, J. Alloys Compd. 210, 243 (1994)

69. S. Takagi, T. Ikeshoji, M. Matsuo, T. Sato, H. Saitoh, K. Aoki, S.-i. Orimo, Appl. Phys. Lett. 103, 113903 (2013)

70. T. Sato, S. Takagi, M. Matsuo, K. Aoki, S. Deledda, B.C. Hauback, S. Orimo, Mater. Trans. 55, 1117 (2014)

71. J.N. Becker, J. Bauer, A. Giehr, P.I. Chu, N. Kunkel, M. Springborg, H. Kohlmann, Inorg. Chem. 53, 1135 (2014)

72. W. Bronger, K. Jansen, P. Müller, J. Less-Common Met. 161, 299 (1990)

73. W. Bronger, G. Auffermann, J. Alloys Compd. 187, 81 (1992)

74. G. Dieter, (US3164441 A, 1965)

75. H.B.H. Cooper, (US3473899 A, 1969)

76. M. Paskevicius, M.B. Ley, D.A. Sheppard, T.R. Jensen, C.E. Buckley, Phys. Chem. Chem. Phys. 15, 19774 (2013)

77. T.D. Humphries, G.N. Kalantzopoulos, I. Llamas-Jansa, J.E. Olsen, B.C. Hauback, J. Phys. Chem. C 117, 6060 (2013)

78. J. Urgnani, F.J. Torres, M. Palumbo, M. Baricco, Int. J. Hydrogen Energy 33, 3111 (2008)

79. J.E. Olsen, M.H. Sørby, B.C. Hauback, J. Alloys Compd. 509, L228 (2011)

80. I. Saldan, Cent. Eur. J. Chem. 9, 761 (2011)

81. E. Jeon, Y. Cho, J. Alloys Compd. 422, 273 (2006)

82. S.-J. Hwang, R.C. Bowman, J.W. Reiter, Rijssenbeek, G.L. Soloveichik, J.-C. Zhao, H. Kabbour, C.C. Ahn, J. Phys.

Chem. C 112, 3164 (2008)

83. T.D. Humphries, M.B. Ley, C. Frommen, K.T. Munroe, T.R. Jensen, B.C. Hauback, J. Mater. Chem. A 3, 691 (2015)

84. I. Saldan, S. Hino, T.D. Humphries, O. Zavorotynska, M. Chong, C.M. Jensen, S. Deledda, B.C. Hauback, J. Phys.

Chem. C 118, 23376 (2014)

85. P. Ngene, R. van den Berg, M.H.W. Verkuijlen, K.P. de Jong, P.E. de Jongh, Energy Environ. Sci. 4, 4108 (2011)

86. P. Martelli, R. Caputo, A. Remhof, P. Mauron, A. Borgschulte, A. Züttel, J. Phys. Chem. C 114, 7173 (2010)

87. J. Mao, Z. Guo, I.P. Nevirkovets, H.K. Liu, S.X. Dou, J. Phys. Chem. C 116, 1596 (2012)

88. N.A. Lange, Lange's Handbook of chemistry. $11^{\text {th }}$ edn. (McGraw-Hill, New York, 1973)

89. D.O. Jordan, J.E. Lane, Aust. J. Chem. 18, 1711 (1965)

90. A.E. Finholt, A.C. Bond, H.I. Schlesinger, J. Am. Chem. Soc. 69, 1199 (1947)

91. E.C. Ashby, G.J. Brendel, H.E. Redman, Inorg. Chem. 2, 499 (1963)

92. L.I. Zakharkin, V.V. Gavrilenko, Dokl. Akad. Nauk. SSSR 145, 793 (1962)

93. B. Bogdanović, U. Eberle, M. Felderhoff, F. Schueth, Scr. Mater. 56, 813 (2007)

94. S.D. Beattie, G.S. McGrady, Int. J. Hydrogen Energy 34, 9151 (2009)

95. B. Bogdanović, M. Felderhoff, M. Germann, M. Hartel, A. Pommerin, F. Schüth, C. Weidenthaler, B. Zibrowius, J.

Alloys Compd. 350, 246 (2003) 
96. B. Bogdanović, M. Felderhoff, G. Streukens, J. Serb. Chem. Soc. 74, 183 (2009)

97. H.W. Brinks, C.M. Jensen, S.S. Srinivasan, B.C. Hauback, D. Blanchard, K. Murphy, J. Alloys Compd. 376, 215 (2004)

98. M. Felderhoff, K. Klementiev, W. Grunert, B. Spliethoff, B. Tesche, J.M. Bellosta von Colbe, B. Bogdanovic, M. Hartel, A. Pommerin, F. Schüth, C. Weidenthaler, Phys. Chem. Chem. Phys. 6, 4369 (2004)

99. K.J. Gross, G. Sandrock, G.J. Thomas, J. Alloys Compd. 330, 691 (2002)

100. T.D. Humphries, D. Birkmire, B.C. Hauback, G.S. McGrady, C.M. Jensen, Phys. Chem. Chem. Phys. 15, 6179 (2013)

101. T.D. Humphries, J.W. Makepeace, S. Hino, W.I.F. David, B.C. Hauback, J. Mater. Chem. A 2, 16594 (2014)

102. M.P. Pitt, P.E. Vullum, M.H. Sørby, H. Emerich, M. Paskevicius, C.J. Webb, E.M. Gray, C.E. Buckley, J.C. Walmsley, R. Holmestad, B.C. Hauback, Int. J. Hydrogen Energy 37, 15175 (2012)

103. D.L. Sun, S.S. Srinivasan, G.R. Chen, C.M. Jensen, J. Alloys Compd. 373, 265 (2004)

104. H. Diaz, A. Percheron-Guégan, J.C. Achard, C. Chatillon, J.C. Mathieu, Int. J. Hydrogen Energy 4, 445 (1979)

105. W. Luo, J.D. Clewley, T.B. Flanagan, W.A. Oates, J. Alloys Compd. 185, 321 (1992)

106. D. Shaltiel, I. Jacob, D. Davidov, J. Less-Common Met. 53, 117 (1976)

107. F. Schüth, B. Bogdanović, M. Felderhoff, Chem. Commun., 2249 (2004)

108. W. Luo, K.J. Gross, J. Alloys Compd. 385, 224 (2004)

109. B. Bogdanović, M. Schwickardi, J. Alloys Compd. 253, 1 (1997)

110. D.A. Sheppard, M. Paskevicius, T.D. Humphries, M. Felderhoff, G. Capurso, J.B.v. Colbe, M. Dornheim, T. Klassen, P.A. Ward, J.A. Teprovich, C. Corgnale, R. Zidan, D.M. Grant, C.E. Buckley, Applied Physics A submitted for publication, APYA-D-15-01460, (2015)

111. R. Urbanczyk, K. Peinecke, M. Felderhoff, K. Hauschild, W. Kersten, S. Peil, D. Bathen, J. Alloys Compd. 385, 224 (2014)

112. R. Urbanczyk, S. Peil, D. Bathen, C. Heßke, J. Burfeind, K. Hauschild, M. Felderhoff, F. Schüth, Fuel Cells 11, 911 (2011)

113. J.M. Bellosta von Colbe, G. Lozano, O. Metz, T. Bücherl, R. Bormann, T. Klassen, M. Dornheim, Int. J. Hydrogen Energy 40, 2984 (2015)

114. G.A. Lozano, C.N. Ranong, J.M. Bellosta von Colbe, R. Bormann, J. Hapke, G. Fieg, T. Klassen, M. Dornheim, Int. J. Hydrogen Energy 37, 2825 (2012)

115. J.M.B. von Colbe, O. Metz, G.A. Lozano, P.K. Pranzas, H.W. Schmitz, F. Beckmann, A. Schreyer, T. Klassen, M. Dornheim, Int. J. Hydrogen Energy 37, 2807 (2012)

116. D. An, P.B. Sunderland, D.P. Lathrop, Fire Saf. J. 58, 204 (2013)

117. G.H. Bulmer, Institution of Chemical Engineers: Symposium Series 33, 79 (1972)

118. S. Kraemer, No drama as SolarReserve commissions world's largest CSP tower with storage. (2014), http://social.csptoday.com/markets/no-drama-solarreserve-commissions-world\%E2\%80\%99s-largest-csp-towerstorage, Accessed 9th September 2015

119. M.G. Barker, D.J. Wood, J. Less-Common Met. 35, 315 (1974)

120. O.K. Chopra, J.Y.N. Wang, K. Natesan, Review of Sodium Effects on Candidate Materials for Central Receiver Solar-Thermal Power Systems, (Argonne, Illinois, USA, 1979), ANL-79-36

121. J. Zhang, R. Kapernick, T.F. Marcille, Nucl. Sci. Eng. 160, 75 (2008)

122. K. Natesan, Y. Momozaki, M. Li, D.L. Rink, Corrosion Performance of Advanced Structural Materials in Sodium, (Argonne, Illinois, USA, 2010), ANL-GenIV-163

123. J.D. Gracie, J.J. droher, A Study of Sodium Fires, (Canoga Park, California, USA, 1960), NAA-SR-4383

124. C. Fluegeman, T. Hilton, K.P. Moder, R. Stnkovich, Process Saf. Prog. 24, 86 (2005)

125. W.D. Boehmer, R.K. Hilliard, Sodium Fire Protection by Space Isolation, Open Catch Pan and Nitrogen Flooding FFTF Proof Test F5, (Richland, WA, USA, 1975), HEDL-TME 75-98

126. R.K. Hilliard, R.P. Johnson, D.A. Powers, In International Working Group on Fast Reactors Specialists' Meeting-on "Sodium Fires, Design and Testing", (Hanford Engineering Development Laboratory, Richland, Washington, USA., 1982), p. 4

127. Unusual Occurences During LMFR Operation, (Vienna, 2000), IAEA-TECDOC-1180

128. Y.F. Khalil, S.M. Opalka, B.L. Laube, Process Saf. Environ. Prot. 91, 463 (2013)

129. A. Chaise, P. de Rango, P. Marty, D. Fruchart, S. Miraglia, R. Olivès, S. Garrier, Int. J. Hydrogen Energy 34, 8589 (2009) 